\title{
Open Competition or Discrimination on Tracks? Examples of Anti-competitive Behaviour of the Deutsche Bahn
}

\section{Tomáš Nigrin ${ }^{1}$}

\begin{abstract}
The article provides an analysis of a competitive situation in railway transport in Germany and defines areas where the Deutsche Bahn holding, which integrates both infrastructure operators and carriers, may behave in an anti-competitive way. First of all, conditions of liberalisation in German railways and position of competition in partial sections of transport are introduced. Subsequently, areas which are - from the economic point of view - necessary for operation of competition in the railway sector are identified: it is the height of fees charged for utilisation of transport routes, fees for the use of railway stations, and finally, traction energy fees, too.
\end{abstract}

On the basis of research into development in the last two decades, steps which are possible to consider to be (minimally) concealed anti-competitive behaviour of the Deutsche Bahn, was were revealed in all areas. This is substantiated by decisions of several decisive regulatory authorities, most predominantly of Bundesnetzagentur and courts, which have repeatedly ordered Deutsche Bahn to revise price lists and other terms.

In consequence, the example of Deutsche Bahn demonstrated a great disadvantage of an integrated company including infrastructure administrator and carrier, as it is offered a great space for influencing competitive environment. In the German example, this often comprised in raising competitor's costs which, however, do not manifest themselves in economic results of the holding company. Should transport policies of the state decide to separate the infrastructure administrator and the carrier, a great deal of hard-to-reveal and thus punishable "complications" preventing establishment of conditions of free competition on the railway market shall cease to exist.

Key words: railway; concurrence; Germany; Deutsche Bahn

JEL: L22, L43, L92, R41

\section{Introduction}

Having successfully reformed its railways, fulfilled and implemented requirements of the so called railroad packages prescribed by European Commission and methodically developed legislative related to abiding by the rules of economic competition, including competences of regulatory authorities of public administration, Bundeskartellamt and Bundesnetzagentur, Germany is one of the countries which may boast with most

\footnotetext{
${ }^{1}$ Charles University in Prague, Faculty of Social Sciences, Institute of International Studies, U Kř́žze 8, 15000 Praha 5; nigrin@fsv.cuni.cz
} 
advanced liberalisation of railway transport. Although Germany is an example for many (not only) European countries, the market status quo in the railway sector shows a whole lot of imperfections and faults that are being done away with very slowly only. A great deal of them is based on the fact that Deutsche Bahn is a holding: on the one hand, the company is a carrier, but simultaneously, it is an infrastructure administrator which sets approximate conditions of infrastructure use, and is supposed to provide equal access to tracks to all carriers involved. This article tries to analyze the situation on the liberalized railroad market in Germany, and identifies concealed anti-competitive steps made by the Deutsche Bahn in areas crucial for setting competitive conditions present in the market. It as a brand new phenomenon which comes through in more advanced phases of railroad market liberalisation only, or more precisely, in the case of integration of infrastructure administrator and carrier into a single company upon failure of (internal or external) control mechanisms.

The research, results of which are presented in this article, is focusing on three main areas which have the greatest impact on setting conditions influencing the cost side of operation on railway. The fourth field, where can be detected discriminatory behaviour of Deutsche Bahn, is the general distribution of the train tickets. Since this is not directly connected with the train operation costs, it will not be discused in this article. The three main areas shall be presented in three case studies: fees for the use of infrastructure, predominantly fees for the use of tracks and railway stations, and for the traction current. These three areas altogether form most of variable costs connected with a train journey. The anti-competitive behaviour of the Deutsche Bahn was revealed in all three areas under observation; in particular it was found in the setting of conditions and fee structures which - in many cases - were highly disadvantageous for competitors of the Deutsche Bahn. The analysis focused methodically on the fee structure development since the beginning of German railway liberalisation in the 1990s until now. A more prominent entry of competition on German tracks after 2000 resulted in an increase of pressure on changes of tariff setting, which were - in many cases - decided at a court. Including a longer period of time into our research enabled us to steer clear from a possible erroneous conclusion stemming from an overtly tight time probe, where an unintentional mistake by the infrastructure administrator in setting the fees could occur. This is eliminated by continual representation; and although the research result is not quantified and does not quantify financial impacts of discrimination on competitors, serious systemic imperfection and continuity of hidden soft discrimination of competition occurs, in which regulatory authorities can hardly intervene. In result, it will be possible to stipulate structural disadvantages for free competition in the railway sector bore by integrated companies incorporating both the function of infrastructure administrator and carrier.

The position of competition on German railway and the problems it encounters come out from the actual configuration and relation of the infrastructure administrator and the former monopolistic national carrier. Germany decided on adopting the strategy of holding configuration, where the Deutsche Bahn is both infrastructure administrator and majority carrier in passenger regional transport, passenger long-distance transport and freight transport. The introductory chapter attempts to explain the development of liberalisation of German railway from its beginning until now, and to describe the state 
which enabled creation of specific conditions, where hidden discrimination against competition on tracks occurs. Market survey carried out by Bundesnetzagentur (Bundesnetzagentur 2011, Bundesnetzagentur 2012a), reports by Monopollkommission (Monopollkommission 2011) assessing the state of market liberalisation of the sector, and annual reports of the Deutsche Bahn (Deutsche Bahn 2005, Deutsche Bahn 2011) were the main sources of information and data presented in this research. Therefore, these were verified macro data supplemented by interpretation. Simultaneously, other sources were taken advantage of, too - professional journals focusing on railroad, where operational views regarding the questions under observation were acquired.

\section{Railroad Reform and the Deutsche Bahn}

Efforts to reform the railway sector, including the Deutsche Bundesbahn, the national monopolistic carrier, begun in Germany at the end of the 1980s. The original plans were to a great extent influenced by development in Great Britain, and by principles of common European transport policies which were being established at that time. After 1994, when the reform of railways in Germany had already begun, clearing off debts occurred and accounting of individual operational parts of the Deutsche Bahnwere separated, i.e. long-distance passenger transport, regional passenger transport, freight transport, management of the transport route, railway stations and services, and besides that, many smaller companies whose activities were connected with railway operation and realties owned by the Deutsche Bahn (Engartner 2008, p. 144). The Deutsche Bahn was converted into a holding company in 1999, in which all constituents mentioned above were included as subsidiary companies. Therefore, complete disconnection of the infrastructure administrator and monopoly carrier did not come about - it remained a part of the Deutsche Bahn (Tomeš 2011, p. 2).

During the railway reform in Germany, powers of newly created regulatory authorities were determined and defined. These regulatory authorities were supposed to focus on respecting conditions of open market environment. Bundeskartellamt is the supreme authority supervising free competition in Germany. When it comes to network industries, a specialized regulatory authority was developed - Bundesnetzagentur für Elektrizität, Gas, Telekommunikation, Post und Eisenbahnen - which has been supervising access to railroad and preventing discriminatory anti-competitive behaviour since 2006. Last but not least, a great number of disputes among carriers are dealt with by regional courts.

The journey leading to implementation of a non-discriminatory competitive environment in railway sector is long indeed, and is fringed by an array of problems and controversies. Regardless of whether it is in Great Britain, Germany or the Czech Republic, nowhere and never shall railways be a 'competition-friendly' environment, as carriages, operation background and operation itself are very costly, and their utilisation is greatly limited by operation conditions (power supply system, axle pressure, cant ratios or transit profile). It is imperative to be knowledgeable about a vast number of various standards and norms, which - together with the necessity to pass an array of corresponding tests - decreases flexibility of hiring labour forces (Kvizda 2010, p. 69).

Liberalisation in the railway sector opened a door to the transport market to many companies which are competitors of the Deutsche Bahn in flexibility, pricing and level 
of services. However, companies within the Deutsche Bahn holding refuse to leave their positions without a fight, to some extent capitalizing on "soft" advantages stemming from their size and configuration. These obstacles in the way of free market are hard to punish and do away with by regulatory authorities; at the same time, they impugn profitability of competitors. Therefore, opening of transport market in Germany developed into a dragging struggle of former monopolies, now separated into individual operation companies: the Deutsche Bahn on one side, competing carriers on the other. This resulted in the fact that the legal framework of market environment in the railway sector had to be redefined and particularized many times (Seidenglanz 2005).

As far as comparison of international statistics is concerned, Germany occupies a very high position: internationally acknowledged IBM Rail Liberalisation Index has repeatedly appraised Germany as a country with the third most liberal market in the railway transport sector. In addition to that, Germany has achieved the same results in the case of component indexes as well: LEX Index and ACCESS Index (Tomeš 2011, p. 144). The former judges legal framework of the market liberalisation, the latter evaluates the degree of real discrimination upon entry of a carrier into the sector (Rail Liberalisation Index 2011). On the basis of the IBM Index, we could therefore say that conditions of the railway sector in Germany are nearly ideal - no discrimination in the market, no barriers upon entry into the sector, or in operation. Nonetheless, the IBM Index is not the only indicator of the state of liberalisation in German railways. Its methodology comes out of survey carried out among representatives of transport companies, experts on transport and representatives of authorities (Rail Liberalisation Index 2011). Therefore, it is different to analyses of market conditions carried out by Bundesnetzagentur which, since 2006 when it was appointed to be the regulator for the sector of railway transport, too, has been executing market researches. These, unlike the methodology of IBM Index, work mainly with data and information provided by operators of railway transport. Bundesnetzagentur strives to find out and quantify views of railway transporters on liberalisation of German railways, and to define the main problems on the basis of operation experience. Unlike researches by IBM, the research does not attempt to compare the state of liberalisation in German railways with other countries. As a result, however, surveys made by Bundesnetzagentur describe the situation in the German railway sector as more grim that it actually is.

The report of Bundesnetzagentur deals with the whole segment of transport market in the railway sector to a great detail, and defines its most serious weaknesses. Its results enable us to select several points which were subjected to most severe criticism by the railway transporters. Within the bounds of transport market openness, the following in particular is criticised: condition of the tariff and sale of tickets (the average mark 3.5), ${ }^{2}$ international access (3.4), and quality and condition of the network construction (3.1) (Bundesnetzagentur 2012a, p. 23). In the area of access into the transport route, it is mainly the state of network construction (3.2), intactness of the network (3.1) and planning of closure activities (2.8) (Bundesnetzagentur 2012a, p. 24). When it comes to access to railway service and infrastructure facilities, carrier were most critical about

\footnotetext{
${ }^{2}$ Value 1.0 being the best, 5.0 being the worst.
} 
openness of side tracks and stations (2.9), shunting yards (2.7), ${ }^{3}$ access to terminals and link-up trailers into the main network (2.6) (Bundesnetzagentur 2012a, p. 26). Upon ascertaining opinions on discriminatory character of fees for use of infrastructure construction, the worst results were recorded for traction current (3.1), shunting yards (2.8), and freight terminals (2.8) (Bundesnetzagentur 2012a, p. 37). A subsequent inquiry strived to find out among carriers the degree of satisfaction with fees for the use of infrastructure which would take value for the money into consideration: the fee for stopping of a train in a station and a stop (3.4), fee for traction energy (3.3), fee for side tracks (3.1) and fee for transport route (3.0) were assessed as the worst (Bundesnetzagentur 2012a, p. 39).

The reason for a fairly bad evaluation of many areas, where equal access of all carriers is clearly ordained by the economic competition law, dwells in the system and height of fees for the use of infrastructure as defined by the Deutsche Bahn. Their structure demonstrates a great degree of protectionism among affiliated companies of the Deutsche Bahn holding. Internconnection of the Deutsche Bahn holding structure is strengthened by the fact that all executives of all companies within the Deutsche Bahn holding are rewarded depending on economic results of the holding as a whole. Therefore, managers are not primarily involved in economic results of "their" affiliated company, for they can take advantage of internal financial transfers. This would prove the fact that Deutsche Bahn exploit the method of raising competitors' costs - increased costs of affiliated companies within the Deutsche Bahn holding are balanced out in the economic results of Deutsche Bahn. However, this behaviour financially hurts competition (Engartner 2008, p. 200).

An interesting view of the economic results of Deutsche Bahn and its individual components is offered by the overview of annual gross profits (EBIT) in 2005 and 2011. After 2005, regulation of the railway transport market through Bundesnetzagentur was strengthened, and business activities of competitors in transport sector were intensified. The legal framework and regulation improved in this period, resulting in supposed decrease of discriminatory potential in the railway transport sector. In reality, however, what happened was that management structure of Deutsche Bahn changed, which positively impacted those parts of the holding which were infrastructure administrators and which determined the fees for its use. First, the chart shows profits of EBIT in 2005 and 2011, including their increase in per cents. The last two columns speak about proportional share of the holding companies' profit on the total economic results of the concern. These data - for clarity displayed by a chart - show profit increase of DB Netz which provides and maintains railway infrastructure. Its profit was exceeded by DB Regio only providing (mostly greatly subsidized) regional transport. Operation of railway stations (approximately 10\%) participates in the profit creation considerably (Deutsche Bahn 2005, p. 144-145, Deutsche Bahn 2011, p. 176-177). Although discretion is advised when looking at the data (for companies were restructuralised in the period under observation - especially in the area of freight transport, logistics, and

${ }^{3}$ In Germany, nine shunting yards shall remain in operation after rationalisation measures have been taken by Deutsche Bahn: Maschen, Seelze, Seddin, Halle, Hagen-Vorhalle, Gremberg, Mannheim, Nürnberg and Munich. Thus, the question is related to access to these yards in particular. 
in the fact that foreign acquisitions of Deutsche Bahn in passenger transport were channelled to DB Arriva), they clearly indicate substantial trends towards change of the holding profit structure in the observed period. The unprecedented profit increase of DB Netze can serve as a proof of Deutsche Bahn strategy aimed on retarding and emasculating access of competitors to German tracks by the means of increasing (for itself and competitors alike) fees for the use of infrastructure. The fact that Deutsche Bahn is structured as a holding makes such steps much easier (Engartner 2008, p. 200).

Table 1: An Overview of EBIT Profit of the Main Parts of Deutsche Bahn Holding, Including the Increase and Expression of Proportional Share on the Total EBIT Profit of the Deutsche Bahn Holding in 2005 and 2011.

\begin{tabular}{|c|c|c|c|c|c|}
\hline & $\begin{array}{c}2005 \\
(\mathrm{mil} €)\end{array}$ & $\begin{array}{l}\text { 2011(mil } \\
€)\end{array}$ & $\begin{array}{l}\text { Difference } \\
2005 / 2011 \\
\text { (multiples) }\end{array}$ & $\begin{array}{c}\text { Percentage of profit } \\
\text { made by the DB } \\
\text { concern in } 2005 \\
(\%)\end{array}$ & $\begin{array}{l}\text { Percentage of profit } \\
\text { made by the DB } \\
\text { concern in } 2011(\%)\end{array}$ \\
\hline $\begin{array}{l}\text { Long-distance transport } \\
\text { (DB Fernverkehr / DB } \\
\text { Bahn Fernverkehr) }\end{array}$ & 50 & 159 & 3.14 & 4 & 7 \\
\hline $\begin{array}{l}\text { Regional transport } \\
\text { (DB Regio + DB } \\
\text { Stadtverkehr/ DB Bahn } \\
\text { Regio) }\end{array}$ & 554 & 801 & 1.45 & 40 & 37 \\
\hline $\begin{array}{l}\text { Freight transport } \\
\text { (DB Railion / DB } \\
\text { Schenker Rail) }\end{array}$ & 12 & 32 & 2.7 & 1 & 1 \\
\hline $\begin{array}{l}\text { Logistics } \\
\text { (DB Schenker / DB } \\
\text { Schenker Logistics) }\end{array}$ & 257 & 403 & 1.57 & 19 & 18 \\
\hline $\begin{array}{l}\text { Network } \\
\text { (DB Netz / DB Netze } \\
\text { Fahrweg) }\end{array}$ & 17 & 715 & 42.05 & 1 & 33 \\
\hline $\begin{array}{l}\text { Railway station } \\
\text { (DB Personenbahnhöfe } \\
\text { / DB Netzte } \\
\text { /Personenbahnhöfe) }\end{array}$ & 136 & 226 & 1.66 & 10 & 10 \\
\hline DB concern total & $1352 *$ & $2177 *$ & 1.61 & $\mathrm{xx}$ & $\mathrm{xx}$ \\
\hline
\end{tabular}

Note: Prices do not take inflation into consideration.

* The sum of individual items does not correspond to the total economic result of the Deutsche Bahn holding which is influenced by economic results of other affiliated companies, some of which were in red.

Source: Deutsche Bahn. Geschäftsbericht 2005, p 144 and 145; Deutsche Bahn. Geschäftsbericht 2011, $p 176$ and 177. 
Figure 1: Proportional Share of the most Important Companies within the Deutsche Bahn Holding on its EBIT Profit (in \%).

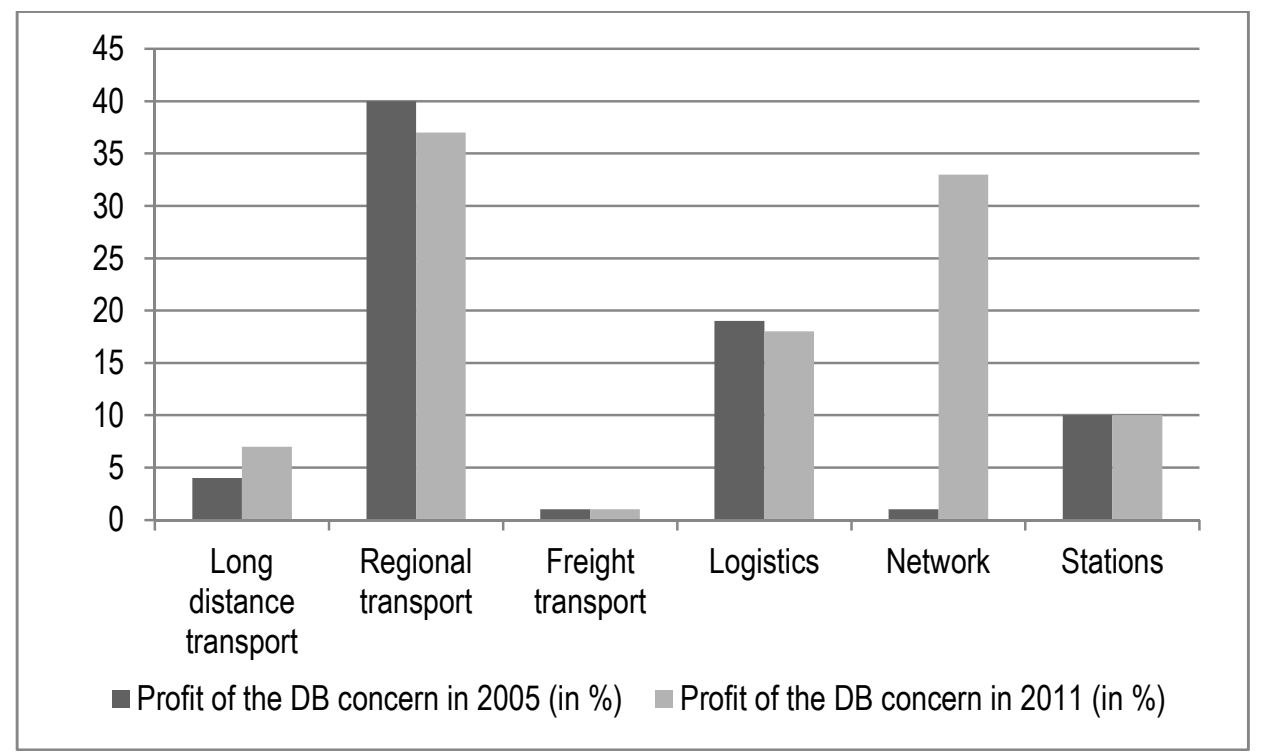

Note: Source data do not take inflation into consideration.

Source: Deutsche Bahn. Geschäftsbericht 2005, p 144 and 145; Deutsche Bahn. Geschäftsbericht 2011, $p 176$ and 177.

\section{Fees for the Use of Transport Route}

Determination of the fee for the use of track infrastructure is the basic presupposition for creating market environment in the railway sector. This fee should cover costs related to composition of timetable railway operation management, train transit from the perspective of railway infrastructure wear, and to necessary maintenance, or possibly to coverage of investment amortisation. Of course, transparent determination of costs incurred by the company in charge of managing the tracks or controlling traffic is absolutely necessary (Kvizda 2013, p. 71-72).

To determine the price for operation of trains became the pillar of German railroad reform, and in 1994, the first system for determination of fees for the use of transport route in Europe was created in Germany (the so-called Trassenpreissystem - TPS 94). The progress from TPS 94 to its current state, when its several generations have been valid since 2011 and yet another restructuralisation of the tariff is planned, has undergone a long development.

A question of the railway network maintenance and management system was at the beginning of the debate on establishment of fees for the transport route, conception of transport route administration - in other words, whether the transport route and the traffic in it would be administered, or controlled, respectively, by a new, independent organisation, or whether this would be carried out by a Deutsche Bahn operating unit only, whose accounting would be separated - turned out to be the crucial question. 
Despite all warnings by experts, the latter was decided on eventually; administration, management, coordination and control of the railway transport shall remain within the operating scope of Deutsche Bahn (later transformed into a holding) (Tomeš 2011, p. 2). According to the original plan, this arrangement was supposed to correspond to the wording of European Regulation of the Ministerial Council from July 6, 1991, which demanded accounting of operation and administration and management of the transport infrastructure to be separated (Engartner 2008, p. 196), however, more often than not, this configuration has resulted in complications and restrictions for national administrator's competitors. It took nearly 10 years until the tariffs were finally made equal, and all carriers started to pay basically comparable fees (Factiva 2000).

In comparison within Europe, TPS 94 was an important first step in the area of payments for the use of railway transport route. It determined prices of trains on the basis of two main criteria: according to its type and weight, and the category of route. Routes were divided into ten groups based on their quality, amenities and transport potential. A variable value stemming from train speed, its weight and kind (i.e. its classification among one of seven types within passenger transport, and one of five types within freight transport) formed another component of the price. Timekeeping of the train (monitored retrospectively) and its impact on wear of tracks related to total weight of the train played its role in calculation (Deutsches Institut für Wirtschaftsforschung 1997, p. 447-462). This role was stipulated by a coefficient by which the price was multiplied.

From the perspective of railway market, uneven setting of conditions for all carriers, particularly quantity rebates for big transport companies which oftentimes were as high as $20 \%$ of the price, was an element of TPS 94 which was most criticised. However, only Deutsche Bahn qualified for these rebates. Small carriers beginning with a smaller volume of transports were discriminated against from the very beginning by a significantly higher price for the use of railway transport route. Later, during validity of TPS 94, this payment setting in passenger railway transport was criticised greatly, and subsequently changed. Compared to fees for passage of high-speed ICE trains, the price for a train run in regional transport was too expensive, indeed. Here, Deutsche Bahn were criticised for a possible cross-financing of individual types of transport, or for transfer of costs from one product of passenger transport in favour of another one. Later, this criticism resulted in minor adjustments and decrease of the fees for (regional) passenger transport (Deutsches Institut für Wirtschaftsforschung 1997, p. 447-462).

In the ensuing years, the whole TPS 94 system proved not to be sustainable, which was also verified by calculation by Deutsches Institut für Wirtschaftsforschung which claimed that the fees had been set too low, and did not correspond to train operation. In passenger transport, profitability reached 83 per cent, in suburban transport it was 97 per cent, and only 20 per cent in freight transport. This was the reason why this system was substituted by another one after four years - TPS 98 price list (Deutsches Institut für Wirtschaftsforschung 1997, p. 447-462).

As in the previous period, fees for the use of railway transport route were supposed to fully cover costs connected to operation and renewal of the railway infrastructure after 1998. The basic view of the fees had therefore not changed; similarly as legislative it 
was based upon. Innovation of TPS 98 comprised in introduction of a two-stage tariff system carried out through launching of the so-called InfraCard. The "classical" linear tariff enabling access to tracks to occasional carriers remained valid. The linear price list, now called VarioPreis, did not differentiate trains based on their type, e.g. into passenger and freight train. Trains were classified into three basic weight categories, and track category (K1 to K6) was what mattered in determining the fee. Flexibility of train schedules was another element projected itself in the coefficient - from time schedule, ordering of which was most expensive, to trains operating in free slots of timetable graphic (Berndt, Kunz 1999, p. 6). A novelty comprised in the possibility to purchase the so-called InfraCard which applied to partial and fixed sections of railway tracks. The length of these was ordained to $\min .800 \mathrm{~km}$ in long distance transport, 25 $\mathrm{km}$ in regional, and $250 \mathrm{~km}$ in freight transport (Berndt, Kunz 1999, p. 3). An interested person paid a fixed price for this InfraCard, which depended on the length of the section, quality of tracks, and desired speed of the train; in this, the interested person was enabled to draw smaller prices for the actual train operation. This system favoured those carriers predominantly, which operated a great number of trains in a specifically defined section. Costs on a single train decreased with increasing frequency of train runs in the same relation.

Implementation of TPS 98 resulted in another wave of complaints regarding discrimination of smaller carriers, as the system of quantity rebates basically remained. InfraCard was convenient mainly for large carriers, i.e. Deutsche Bahn, save for minor exceptions. In October 1999, Bundeskartellamt therefore instituted proceedings against Deutsche Bahn for a possible misuse of a monopoly position in the market, and for setting disadvantageous conditions, later deciding that TPS 98 set such conditions which "so far have been most convenient for operational units of Deutsche Bahn as the only large customer" (Berndt, Kunz 1999, p. 1). Besides that, Bundeskartellamt found out that the prices smaller carriers paid for the use of railway route were roughly 25 to 40 per cent higher than the price paid by parts of Deutsche Bahn. Therefore, opening of railway transport market did not help TPS 98 either. Being exposed to pressure of Bundeskartellamt, Deutsche Bahn were forced to create a new price list using infrastructure applicable from the beginning of 2001 (Berndt, Kunz 1999, p. 1).

Although creation of the new tariff TPS 01 was supervised by a market regulator, its establishment raised an array of trials. According to announcement of Deutsche Bahn from summer 2000, the tariff was supposed to be effective as of January 1, 2001. However, the deadline was not met, and the price list was introduced as late as April 1, 2000. Competitors refused to pay the difference between fees TPS 98 and TPS 01 since the fees prescribed by the latter tariff were more favourable for smaller carriers. Deutsche Bahn lost most of the cases in the subsequent years (Brauner 2008, p. 618).

An unary tariff which depended on track category regardless of capacity of the given section used by the carrier was the basis of the TPS 01 price list. Its improvement comprised of an increase of track categories to nine. Track load and total train load played their roles, too (Engartner 2008, p. 200). It must be said, though, that the TPS 01 tariff did not remove all problems connected with access of small companies into the market, though the main moment of discrimination, the binary tariff had been removed. Deutsche Bahn made all efforts possible to prevent competition from entering the tracks. With respect to competition, TPS 01 was more unbiased, yet even here it seemed 
so that costs are still being raised above the "appropriate" level in some categories - e.g. in long distance personal transport. Moreover, competitors had to deal with fees for connecting into the infrastructure, or for cancellation, or deliberate undermaintenance of those tracks which were strategically important for competing carriers (Engartner 2008, p. 200).

After 2001, the number of trains operated by private carriers increased on German tracks. Hence, number of disputes regarding setting of fees for the use of transport route increased as well. As far as cost composition is concerned, this fee is very important. DB Netze tried to press a fee raise by approximately 30 per cent in third of the network. This was supposed to concern tracks with dense time operation in regional passenger transport, which met with resentment among competing carriers (BAG-SPNV 2002). Undertaking other steps, DB Netze strived to emasculate one-shot or irregular train runs and prefer affiliated companies from the Deutsche Bahn holding when assigning tracks (Monopollkommission 2011, p. 109-113).

At the beginning of 2013, a revised price system TPS 13 came into force, which complemented and improved the current system. It was cleared away of discriminatory features as had been named by Bundesnetzagentur. Requests regarding assignment of train tracks should be dealt with anonymously by DB Netze, which means that a targeted discrimination of competing carriers should no longer occur. DB Netze are trying to decrease delays and network breakdowns. Its better utilisation should be ensured by a system, where carriages with construction speed lower than $50 \mathrm{~km} / \mathrm{h}$ shall pay more for the use of transport route, and delays brought about by carriers shall increase the price for transport route, too (Monopollkommission 2011, p. 109-113). On the other hand, however, the infrastructure administrator shall compensate for infrastructure breakdowns. General agreements on assignment of routes shall not be possible to cancel entirely; nonetheless, it will be possible to cut down on the volume of train kilometres by no more than 1.5 per cent annually. Besides that, a fee of $€ 80$ shall be collected for each ordered and not used train route. An "introductory" discount from the fee for transport route $(10 \%)$ for new projects and newly acquired transports in favour of railways shall be an interesting stimulus for new transport projects (Deutsche Bahn 2013, p. 9).

The fact that Bundesnetzagentur is defined as a specialized regulatory authority for the railway sector has improved the status quo when it comes to determination of the fee for transport route; nevertheless, it was not capable of preventing Deutsche Bahn from pressing on its competitors entirely. New reasons for limiting access to or not assigning of requested routes keep on emerging, and saying that, it must be noted that Bundesnetzagentur primarily did not manage to procure increase of prices for the use of railway transport route. So while between 2006 and 2011 inflation recorded a 9\% increase, the price of routes for freight transport increased by $16 \%$, for long distance passenger transport by $14 \%$, and finally, for regional passenger transport by $9 \%$ (Bundesnetzagentur 2011, p. 37). In consequence, the Deutsche Bahn concern managed to allocate roughly a third of its resources (minus proceeds from fares) it annually receives from the state budget for regional railway transport through constant increase of fees for the transport route. In 2011 , it was $€ 2.79$ billion out of total $€ 7$ billion which 
were paid out to all railway carriers executing transport in commitment to public services (Rainer 2013, p. 76).

\section{Traction Current}

From the perspective of market liberalisation, traction current and its supply are an area which private railway carriers view as most discriminatory. According to a survey carried out by Bundesnetzagentur, approximately $60 \%$ of carriers expressed their reservations concerning traction current (Bundesnetzagentur 2012, p. 37). The reason for this is that this domain is very complicated as far as technology and infrastructure is concerned, and besides that, no regulatory authority has been named yet which would deal with it in its whole extent. Recent development indicates that in future, these competences might broaden responsibilities of Bundesnetzagentur. Currently (in the beginning of 2013), however, this is not the case yet.

Power grid providing supply of traction energy to electrified routes had always been operated by parts of Deutsche Bahn. Resulting from the German railway reform, this part of activities was separated and assigned to an affiliated holding company DB Energie, whose task is to produce electric energy and maintain all infrastructure - i.e. including traction lines (above tracks), or traction tracks (located next to tracks) in case of certain suburban lines of S-Bahn. In the context of the whole world, DB Energie operates an absolutely unique energy network; it is nearly completely detached from the common mains supply. At the same time, nonetheless, it is capable of meeting $80 \%$ of the demand for traction current (Monopollkommission 2011, p. 85-87).

Up to 1997 , the fee for traction current was a part of payments for railway transport route. In the following period, traction current was billed separately, on the basis of bilateral agreements between carriers and DB Energie. After legislative had changed (mainly competition law), a transparent tariff system had to be introduced. Therefore, a new price list of traction energy was launched in 2003 (Bahnstrompreissystem 2003 BPS 2003) which stated different prices of energy set according to the time of day when it was consumed. BPS 2003 was the first tariff which did not charge flat prices for consumption by electric driving vehicles, but it considered actual consumption provided by measuring equipment installed in each engine. This equipment enabled measuring of current produced by engines when breaking with electric dynamic brake (recuperation), too. A year later, a revised tariff system BPS 04 was introduced, which decreased differences between prices of energy consumed during peaks and outside of them. Prices for traction energy were included in the fee for the use of transport route, and were reimbursed to DB Netze. Factual impossibility to supply energy from suppliers other than DB Energie was another flaw of BPS 04. It was only after a few lawsuits that tariff changes occurred, and the tariff then made it possible to calculate costs for use of railway energy network only, which had been the condition for ordering electric energy from another supplier. According to a federal court of justice decision, Bundesnetzagentur was appointed to play the role of regulatory authority in this component area (Bundesnetzagentur 2012b).

The criticised quantity rebates for consumed energy, this time explicitly intended for companies from the Deutsche Bahn group, once again became the reality of the new tariff system. Therefore, rebates were subjected to sharp criticism, and DB Energie 
announced that they would be cancelled as of December 31, 2012 (Eisenbahnjournal 2012). However, during the second half of 2012, Deutsche Bahn revoked their decision, and a new price list valid for 2013 (BPS 13) contains rebates again. Not only this was criticised sharply by competitors (Henningfeld 2012a), but European Committee instituted proceedings with Deutsche Bahn and DB Energie as suspicions existed that principles of free competition in supplies of traction energy had been breached (Henningfeld 2012b).

The issue of price of recuperated energy remains an important dispute between private carriers on one side, and DB Energie on the other, which has not been settled so far. When braking, engines equipped with electric dynamic brake produce electric energy. If enabled by converter station, it is possible to "return" this energy back into the network and make use of it by another engine. Simply speaking, the current from the engine "flows" into the traction main. The DB Energie price system took this energy into consideration; nonetheless, the company always bought it out from carriers for much lower prices than those applied for the carries upon their purchase of the energy from DB Energie. It is necessary to say that the amount of energy in question is not negligible at all - according to calculations, 5-7 per cent of energy is recuperated by railway vehicles in Germany. In given volumes, the difference between purchasing and selling prices is very important indeed. Though technical equipment of converter stations and the fact that volume of recuperated energy produced is impossible to plan brings additional costs for DB Energie, the question remains whether it is not exceeded by revenues created by the difference between prices of sold and bought energy. Appropriate state regulatory authority has not been named for this field yet, and therefore, it is not possible to subject the prices to any analysis (Monopollkommission 2011, p. 91-100). Generally, the domain of recuperated energy meshes together with efforts of Deutsche Bahn to create disadvantageous conditions for their competitors. The truth is that low price of recuperated energy does not harm Deutsche Bahn, as most of their engines are not capable of recuperating energy. On the other hand, nearly all competitors have engines at their disposal which can recuperate energy, but cannot make use of this competitive advantage because of configuration of the tariff (Eikelberg 2012). 
Figure 2: Traction Energy Price Development Since 2005 (in ct/kWh).

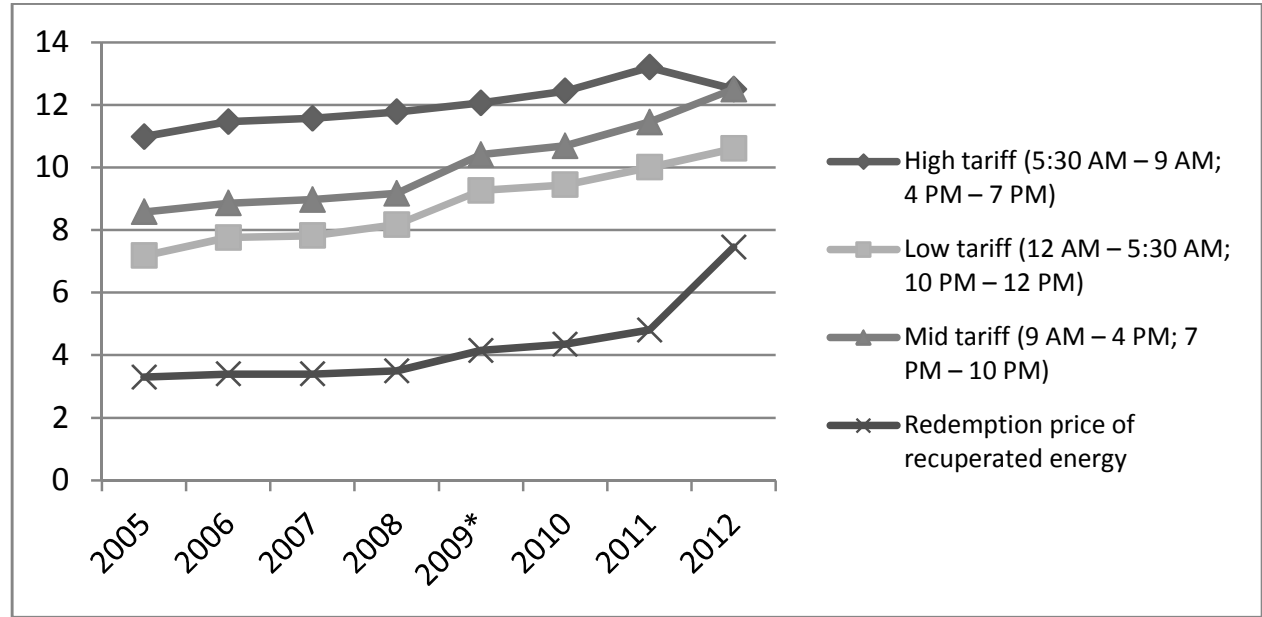

Note: Prices do not take inflation into consideration.

* The prices mentioned are after their decrease during the year.

Source: Bundesnetzagentur: Marktuntersuchung Eisenbahnen 2012, Dezember 2012, p 35.

\section{The Fee for the Use of Station}

Besides progressing opening of railway infrastructure to competition, it was necessary to sort out payments for use of railway stations by trains of competitors. At the beginning of the 1990s, i.e. in a period when nearly all trains were operated by Deutsche Bundesbahn and Deutsche Reichsbahn, all railway stations and related infrastructure were managed and kept by operational units of this company. After the first step of railway reforms had taken place in 1994, however, railway stations were transferred to "network" domain of business activities (Geschäftsbereich Netzt), and after 1999, Deutsche Bahn DB Station und Service AG affiliated company was founded, which was responsible for providing operation of railway stations.

Hence, 1999 was a turning point from which all stops of trains in railway stations in German railroad network were supposed to be paid for separately. This was happening during creating conditions which would allow open economic competition in the railway sector in accordance with regulations of European Committee. Price list, though, was created without paying attention to any obvious methodology, and the price for the use of a railway station by all passing trains was stipulated as a mean. Total costs on operation of a railway station were divided by a number of train stops, which resulted in a list containing approximately 5,400 items; these were the basis for determining the price for the use of individual railway stations (Deutsche Bahn 2010, p. 2).

A price list (SPS 05) based on division of railway stations into six categories according to their quality and services offered came into force in 2005. It provided for prices being calculated for individual federal states separately, thus supposing an array of up to 96 various prices. Pricing policies were primarily founded on facilities of railway stations 
and length of train unit. It was intended that all railway stations of all categories would comprise of a platform (or a place to get on the train from), a sign stating the name of the station, a place where timetable would be posted, a place for installation of ticket machine, a local navigation system, facilities for regular cleaning, litter bins, an information space for transport operators, and services (including safety measures and provisions) were to be covered by one of the 3-S headquarters (3-S being an abbreviation for Service, Sicherheit und Sauberkeit - services, security and cleanness) (Stadt und Bahnhof 2007, p. 2). A railway station of a higher category had to have other facilities and equipment at disposal - for detailed information, please see the chart below.

Length of train units was an important variable determining the price for one stop of a train. Train units of up to 180 metres in length are multiplied by coefficient 1.0, longer ones by 2.0. The actual price for a stop of a train at a train station is calculated through dividing costs connected with maintenance of the railway station by a number of stops of a train, whilst a stop of a train unit longer than 180 metres is calculated as two stops. The price thus corresponds to real costs related to individual railway stations. A single stop of a train with length of up to 180 metres for example at Berlin Hauptbahnhof costed $€ 41.26$ (Stadt und Bahnhof 2007, p. 77).

If a railway station was out of order, or a delay was caused by DB Station und Service including both breakdowns of technical character, and e.g. insufficient or slow maintenance in winter - rebate items were deducted from announced prices. This meant that railway operators had some levers for enforcement of a certain degree of services at particular railway stations (Stadt und Bahnhof 2007, p. 78).

The fact that DB Station und Service is an affiliated company of the Deutsche Bahn holding, and that conditions are set by its internal mechanisms in such a way that would suit other companies within the holding is the centrepiece in criticism of the system presented herein. Moreover, competing carriers have no other option but to accept such condition setting, for there is no option to take advantage of "another" infrastructure. Bundesnetzagentur declared the SPS 05 system null and void in 2009, and Deutsche Bahn were forced to carry out a new pricing system (Stadt und Bahnhof 2007, p. 80).

A valorised price list SPS 11 came into force in 2011, increasing prices for the use of a railway station by ca $3.4 \%$, although the price increase of SPS 05 had been approximately that of $8 \%$ during the six years of its validity. SPS 11 introduced a change in coefficients of train length which were the most important element for determining prices for train stopping in a station. Moreover, it contained a novelty, too category for trains of up to 90 metres in length. Here, the coefficient value remained 1.0 , the coefficient value of trains of up to 170 metres in length was 1.2 , and trains exceeding this length were assigned a coefficient of 3.0. Howbeit fee slightly favoured regional transport; they had a great and hard impact on incoming competitors of Deutsche Bahn in long distance transport. When calculating operating costs, a company which was preparing an express train line from Köln to Hamburg (HKX-Expres) derived from regulations as stipulated in SPS05. Its train units were planned to be 178 metres long (Schlesiger 2012); this meant that it suffered great damage by the tariff changes. Introduction of SPS 11 resulted in proceedings at Bundesnetzagentur which 
invalidated the SPS 11 and called upon Deutsche Bahn to develop a new tariff system valid from 2015. Until then, and from January 1, 2013, a temporary system which shall not include the train length as the factor necessary for calculation of train stopping at a railway station price, shall be in force. In future, only one coefficient for stopping shall exist for trains of regional transport, and one coefficient for long distance transport trains regardless of their length (Henningfeld 2012c).

\section{Conclusion}

Research results presented herein have indeed revealed certain conditions in all areas under observation, setting of which harmed competitors of Deutsche Bahn in German railway sector. If we look closely at this problematic, we can assume that it is not an individual case of Deutsche Bahn, but that it can represent a very serious phenomenon which - in a certain phase of railway market liberalisation - is bound to be seen in all countries, where carrier and infrastructure operator functions are integrated in a single company, even if they have established specialized regulatory bodies. Moreover, in German case, the holding structure of Deutsche Bahn is very labyrinthine, which makes it difficult to monitor flow of cost items. This results in a possibility to transfer costs and revenues within companies inside the holding in such a way, that besides affiliated companies, increased expenses would be borne by competitors, too, whilst expenses would be made equal with corresponding revenues internally, within the holding structure. This mechanism thus leads to a raise of competitors' operational costs, and does not reflect itself in aggregate account balance of the holding.

Our specific view of the situation in Germany showed a status quo, which has existed there for nearly two decades: conditions for activities of competitors are methodically made more difficult in certain segments. An array of specific examples proves that the holding organisation with inclusion of the infrastructure administrator shows many disadvantages and negatively influences market environment in the railway sector. And although accounting of infrastructure operators - DB Netz for transport route, DB Station und Service for railway stations, and DB Energie for traction current infrastructure - had been separated from operational units of the holding, their behaviour indicates only partial success only, as an obvious or hidden privileging of companies within the Deutsche Bahn holding had occurred repeatedly in most of the announced tariffs. In reality, new and new barriers for competitors emerge, and disadvantageous conditions negatively influence economy of their operation.

Legislators react regularly to this fact by incessant refinements of competition terms and by expanding authorities of regulators - predominantly by appointing Bundesnetzagentur to be departmental regulatory authority. However, the Deutsche Bahn holding disposes of (economically and politically) unshakable position, which enables it to keep on making further and further discriminatory steps. As a consequence, Germany shows great results of railway liberalisation, in reality, however, it must deal with a wider spectrum of problems an barriers than other countries, where the company functioning as the infrastructure operator is different than that working as a carrier (current configuration of Správa železniční dopravní cesty in the Czech Republic, for example). And albeit participating politicians, officials and experts are aware of this fact, singling infrastructure operators out of the Deutsche Bahn holding is not debated, let alone that it would be on agenda. Competing carriers therefore have no other option 
but to fight long battles for their rights at courts and regulatory authorities. However it seems to be clear, that the separation model doesn't bring any benefits by itself. The real division (unbundling) may take much more longer, because of the "inertia" of the railway institutions. This is strenghtened by soft factors as a sectoral advantages for the employees of railway institutions as a free travel ticket or common identity etc. The way leading to the best-possible solution is the strengtening of the powers of the regulatory bodies in railway sector.

\section{References}

BAG-SPNV. (2002). Positionspapier der Bundesarbeitsgemeinschaft der Aufgabenträger des SPNV (BAG-SPNV) zur Einführung von Regionalfaktoren im Trassenpreissystem der DB Netz AG, 16.10.2002, retrieved October 17, 2012 from http://spnv.de/website/cms/upload/positionen/Pos02-10-16.pdf.

BERNDT, A., KUNZ, M. (1999). Trassenpreise, InfraCard und Kostendeckung: Diskriminierungsfreier Zugang zum Schienennetz der Deutschen Bahn AG, Diskussionsbeiträge // Institut für Verkehrswissenschaft und Regionalpolitik, No. 64, retrieved May 9, 2012, from http://hdl.handle.net/10419/47639.

BRAUNER, J. R. (2008). Trassenpreissystem der DB Netz AG rechtswidrig. Eisenbahn-Revue International, Heft 12/2008, ISSN 1421-2811.

BUNDESNETZAGENTUR. (2011). Marktuntersuchung Eisenbahnen 2011, Bundesnetzagentur: Bonn.

BUNDESNETZAGENTUR. (2012a). Marktuntersuchung Eisenbahnen 2012, Bundesnetzagentur: Bonn.

BUNDESNETZAGENTUR. (2012b). Bundesnetzagentur genehmigt der DB Energie GmbH etzentgelte und Erlösobergrenzen für das Bahnstromnetz. Pressemitteilung, Bundesnetzagentur, 29.2.2012, retrieved October 17, 2012 from http://www.bundesnetzagentur.de/SharedDocs/Downloads/DE/BNetzA/Presse/Pressemi tteilungen/2012/120229_\%20Bahnstromnetz_pdf.pdf?_blob=publicationFile.

DEUTSCHE BAHN. (2005). Geschäftsbericht 2005.

DEUTSCHE BAHN. (2010). Stationsanzeiger, Nr. 02, prosinec 2010, iretrieved April 30, 2012 from

http://www.deutschebahn.com/site/shared/de/dateianhaenge/publikationen__broschuere n/ub__personenbahnhoefe/stationsanzeiger__022010.pdf.

DEUTSCHE BAHN. (2011). Geschäftsbericht 2011.

DEUTSCHE BAHN. (2013). Das Trassenpreissystem der DB AG, Gültig ab dem 9.12.2012 bis 14.12.2013, retrieved January 17, 2013 from http://fahrweg.dbnetze.com/file/2597008/data/trassenpreisbroschuere_2013.pdf.

DEUTSCHES INSTITUT FÜR WIRTSCHAFTSFORSCHUNG. (1997). Trassenpreise der Deutschen Bahn AG - diskriminierungsfrei und kostendeckend?. Wochenbericht. 64. Jahrgang, Nr. 26/97, 26.6.1997, ISSN 0012-1304. p 547-462. 
EIKELBERG, J. (2012). Netzagentur senkt Durchleitungspreis für Bahnstrom, 1.3.2012, Eisenbahnjournal Zughalt.de, retrieved January16, 2013 from http://www.zughalt.de/2012/03/netzagentur-senkt-durchleitungspreis-fur-bahnstrom/.

EISENBAHNJOURNAL. (2012). Neue Bahnstrompreise werden allgemein positiv aufgenommen, 27.3.2012. Eisenbahnjournal Zughalt.de, retrieved October 17, 2012, http://www.zughalt.de/2012/03/neue-bahnstrompreise-werden-allgemein-positiv-

aufgenommen/.

ENGARTNER, E. (2008). Privatisierung der Deutschen Bahn. Über die Implementierung marktorientierter Verkehrspolitik, Wiesbaden: Verlag für Sozialwissenschaften, ISBN 978-3-531-15796-2, 342 p.

ENGEL, R. (2013). Geschäftsmodell der DB-Infrastruktur vor dem Ende? EisenbahnRevue International, 2/2013.

FACTIVA. (2000). Sechs Jahre Bahnreform - Experten ziehen kritische Bilanz. Algemeiner Deutscher Nachrichtendienst, 11.10.2000, Factiva database.

FACTIVA. (2001). Kaum Wettbewerbauf der Schiene Bundeskartellamt - Ursache alte Trassenpreise, Deutsche-Verkehrszeitung, 21.8.2001. Factiva database.

HENNINGFELD, S. (2012a). Mofair: Schwere Kritik an DB Energie, 12.11.2012, Eisenbahnjournal Zughalt.de, retrieved January 17,

2013http://www.zughalt.de/2012/11/mofair-schwere-kritik-an-db-energie/.

HENNINGFELD, S. (2012b). Bahnstrom: EU-Kommission leitet Kartellverfahren gegen Deutsche Bahn ein, 14.6.2012, Eisenbahnjournal Zughalt.de, retrieved January 17, 2013 from http://www.zughalt.de/2012/06/bahnstrom-eu-kommission-leitetkartellverfahren-gegen-deutsche-bahn-ein/.

HENNINGFELD, S. (2012c). DB Station and Service: Neues Stationspreissystem ab 2013, 4.9.2012, Eisenbahnjournal Zughalt.de, http://www.zughalt.de/2012/09/dbstation-service-neues-stationspreissystem-ab-2013/, retrieved January16, 2013

KVIZDA, M. (2010). Impacts of Unbundling on Competitiveness of Railways. Železniční doprava a logistika, Žilina, Žilinská univerzita, Slovakia. ISSN 1336-7943, 2010, vol. 2010, no. 02, pp. 66-72.

KVIZDA, M. (2013). Regulace konkurenčního prostředí na železnici - čas rozhodnout. In Martin Kvizda a Zdeněk Tomeš. Regulovaná a neregulovaná konkurence na kolejích. Brno: Masarykova univerzita MuniPress, 2013. pp. 93-116, ISBN 978-80-210-6425-6.

MONOPOLLKOMMISSION. (2011). Bahn 2011: Wettbewerbspolitik unter Zugzwang. Sondergutachten der Monopollkommission gemäß \$36 AEG, Sondergutachten 60. Bonn: Mopollkommission.

RAIL LIBERALISATION INDEX. (2011). Rail Liberalisation Index 2011, 20.4.2011, retrieved January 11, 2013 from

http://www.deutschebahn.com/file/2236524/data/study__rail__liberalisation_index_2 011_presentation.pdf.

SCHLESIGER, C. (2012). EU und Bund nehmen die Bahn in die Zange. WirtschaftsWoche, retrieved April 30, 2012, 
http://www.wiwo.de/unternehmen/dienstleister/schienennetz-keine-trennung-von-netzund-bahn/6144800-3.html.

SEIDENGLANZ, D. (2005). Vývoj železniční dopravy v Evropě a její pozice v evropské dopravní politice. Národohospodářský obzor, Brno: ESF MU Brno, 2005, V, No. 4, pp. 92-104. ISSN 1213-2446.

STADT UND BAHNHOF. (2007). Zwischenbericht, 2007, retrieved April 30, 2012 from http://www.stadtundbahnhof.de/1\%20Zwischenbericht.pdf.

TOMEŠ, Z. (2009). Monopol a konkurence na železnici. Scientia et Societas, Praha: NC Publishing, 2009, No. 04, p. 139-149. ISSN 1801-7118.

TOMEŠ, Z. (2011). Competition Limits in Railway Transport. Ekonomický časopis. 59/2011, (2), p. 194-203. ISSN: 0013-3035. 